Article

\title{
Phytoconstituents with Radical Scavenging and Cytotoxic Activities from Diospyros shimbaensis
}

\author{
Per Aronsson ${ }^{1}$, Joan J. E. Munissi ${ }^{2, *}$, Amra Gruhonjic ${ }^{1,3}$, Paul A. Fitzpatrick ${ }^{3}$, \\ Göran Landberg ${ }^{3}$, Stephen S. Nyandoro ${ }^{2, *}$ and Mate Erdelyi ${ }^{1,4, *}$ \\ Received: 10 December 2015; Accepted: 30 December 2015; Published: 15 January 2016 \\ Academic Editor: Esra Capanoglu \\ 1 Department of Chemistry and Molecular Biology, University of Gothenburg, Gothenburg SE-412 96, Sweden; \\ aronsson.per.m@gmail.com (P.A.); amragruhonjic@hotmail.com (A.G.) \\ 2 Chemistry Department, College of Natural and Applied Sciences, University of Dar es Salaam, \\ P.O. Box. 35061, Dar es Salaam 0255, Tanzania \\ 3 Sahlgrenska Cancer Center, University of Gothenburg, Gothenburg SE-405 30, Sweden; \\ paul.fitzpatrick@gu.se (P.A.F.); goran.landberg@gu.se (G.L.) \\ 4 Swedish NMR Center, University of Gothenburg, Gothenburg SE-405 30, Sweden \\ * Correspondence: joan.munissi@udsm.ac.tz (J.J.E.M.); nyandoro@udsm.ac.tz (S.S.N.); \\ mate@chem.gu.se (M.E.); Tel.: +255-754-206-560 (S.S.N.); +46-766-22-9033 (M.E.)
}

\begin{abstract}
As part of our search for natural products having antioxidant and anticancer properties, the phytochemical investigation of Diospyros shimbaensis (Ebenaceae), a plant belonging to a genus widely used in East African traditional medicine, was carried out. From its stem and root barks the new naphthoquinone $8,8^{\prime}$-oxo-biplumbagin (1) was isolated along with the known tetralones trans-isoshinanolone (2) and cis-isoshinanolone (3), and the naphthoquinones plumbagin (4) and $3,3^{\prime}$-biplumbagin (5). Compounds 2,4 , and 5 showed cytotoxicity $\left(\mathrm{IC}_{50} 520-82.1 \mu \mathrm{M}\right)$ against MDA-MB-231 breast cancer cells. Moderate to low cytotoxicity was observed for the hexane, dichloromethane, and methanol extracts of the root bark $\left(\mathrm{IC}_{50} 16.1,29.7\right.$ and $>100 \mu \mathrm{g} / \mathrm{mL}$, respectively), and for the methanol extract of the stem bark $\left(\mathrm{IC}_{50} 59.6 \mu \mathrm{g} / \mathrm{mL}\right.$ ). The radical scavenging activity of the isolated constituents (1-5) was evaluated on the 2,2-diphenyl-1-picrylhydrazyl (DPPH) radical scavenging assay. The applicability of the crude extracts and of the isolated constituents for controlling degenerative diseases is discussed.
\end{abstract}

Keywords: Diospyros shimbaensis; Ebenaceae; tetralones; naphthoquinoes; radical scavenging; cytotoxicity; MDA-MB-231; DPPH

\section{Introduction}

The genus Diospyros (Ebenaceae) comprises of approximately 500 species distributed in the tropical and subtropical regions of both hemispheres. Several Diospyros species are known for their timber and edible fruits, e.g., D. kaki, D. kirkii [1], and are used in traditional medicine. For example, D. lycioides is applied against dental infections [2,3], D. maritima against rheumatism [4,5], D. kirkii against fever and gonorrhea [6], and D. usambarensis as antidote against snake bite [6-8]. In Tanzania, the root decoctions of $D$. fischeri are taken against stomach aches, chest complaints, gonorrhea, and dry cough. The roots and leaves of D. usambarensis are used for the treatment of stomach pain, constipation, rashes, cervical prolapse, epilepsy, malaria, measles, psychiatric disorders, sterility, and joint pain, whereas those of D. verrucosa for the treatment of psychiatric disorders and its fruits against asthenia [9]. This extensive traditional medicinal use of the Diospyros genus suggests its richness in bioactive secondary metabolites. Accordingly, the isolation of triterpenoids, coumarins, naphthols, phenols, and naphthoquinones from this genus was reported $[10,11]$. D. shimbaensis, a small tree native to East Africa, 
has not yet been phytochemically investigated. It has very limited geographical distribution with a minimal remaining population, and was therefore red-listed by IUCN as an endangered species [12]. In order to support its domestication and to avoid an unfortunate loss of phytochemical information and bioactive compounds that may be of medicinal interest, we have investigated its stem and root barks constituents for radical scavenging and cytotoxic properties.

\section{Results and Discussion}

\subsection{Isolation and Identification of Compounds}

The air dried stem bark of $D$. shimbaensis was extracted by soaking in methanol at room temperature for $48 \mathrm{~h}$. Its root bark was extracted consecutively in isohexane, dichloromethane, and methanol, by soaking at room temperature for $48 \mathrm{~h}$ each. The methanol extracts of the stem and root barks were separately subjected to purification by high-performance liquid chromatography (HPLC) yielding five compounds (Figure 1), which were identified by NMR spectroscopic and mass spectrometric analyses.

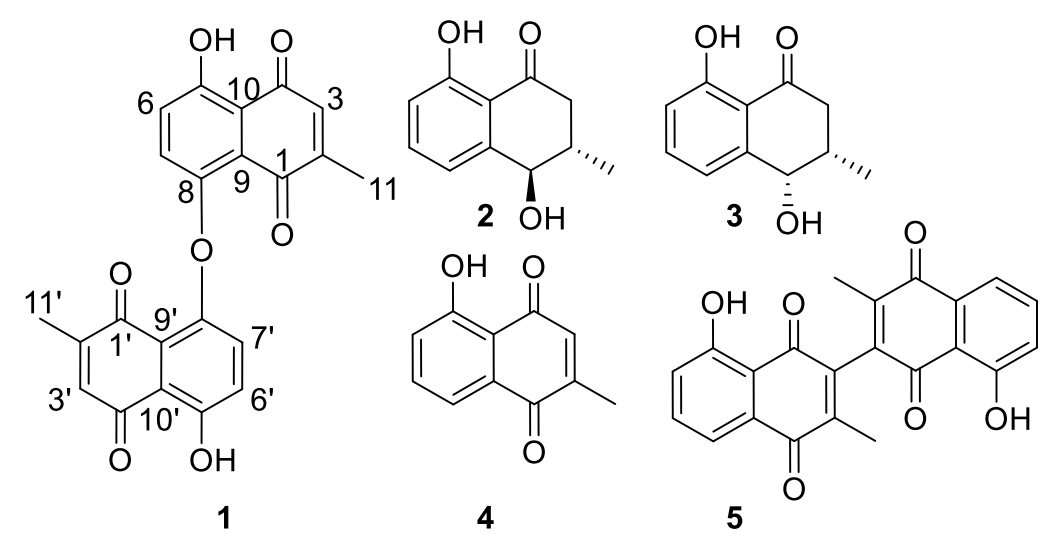

Figure 1. Compounds 1-5 isolated from D. shimbaensis.

Compound 1 (Figure 1) was obtained as a yellow amorphous solid. Its HR(ESI)MS analysis along with its ${ }^{13} \mathrm{C}$-NMR data indicated the molecular formula $\mathrm{C}_{22} \mathrm{H}_{15} \mathrm{O}_{7}$ (obs $\mathrm{m} / z$ 391.0892, calcd 391.0818, $\left.[\mathrm{M}+\mathrm{H}]^{+}\right)$. Two carbonyl groups at $\delta_{\mathrm{C}} 190.5$ and $\delta_{\mathrm{C}} 185.2$, and eight aromatic carbons (Table 1) were observed in its ${ }^{13} \mathrm{C}$-NMR spectrum, consistent with a 1,4-naphthoquinone skeleton. Its aromatic $\mathrm{AB}$ spin system $\delta_{\mathrm{H}} 7.29\left(\mathrm{H}-6\right.$ and $\left.\mathrm{H}-6^{\prime}\right)$ and $\delta_{\mathrm{H}} 7.20\left(\mathrm{H}-7\right.$ and $\left.\mathrm{H}-7^{\prime}\right)$ with $J=8.6 \mathrm{~Hz}$ along with a broad singlet at $\delta_{\mathrm{H}} 12.58\left(5-\mathrm{OH}\right.$ and $\left.5^{\prime}-\mathrm{OH}\right)$, typical of a hydrogen bonded phenol, were consistent with a 5,8-disubstituted benzene ring of a 1,4-naphthoquinone. The observation of a quartet at $\delta_{\mathrm{H}} 6.80\left(\mathrm{H}-3\right.$ and $\left.\mathrm{H}-3^{\prime}\right)$ and a doublet at $\delta_{\mathrm{H}} 2.01\left(\mathrm{H}-11\right.$ and $\left.\mathrm{H}-11^{\prime}\right)$, with $J=1.6 \mathrm{~Hz}$, suggested the presence of a quinonoid proton neighboring a methyl group. HMBC correlations of this methyl to C-1/C-1',$C-2 / C-2^{\prime}$ and C-3/C-3' were consistent with its placement at C-2/C-2', which also is in good agreement with the biogenesis of plumbagin-type napthoquinones [13]. The quinonoid $\mathrm{H}-3 / \mathrm{H}-3^{\prime}$ proton $\left(\delta_{\mathrm{H}} 6.81\right)$ exhibited HMBC correlations to $\mathrm{C}-10 / \mathrm{C}-10^{\prime}\left(\delta_{\mathrm{C}} 115.5\right)$, which carbon also showed correlations to H-6/H-6' $\left(\delta_{\mathrm{H}} 7.29\right)$, confirming the orientation of the rings of the naphthoquinone skeleton of 1 . HMBC correlations of $5-\mathrm{OH} / 5^{\prime}-\mathrm{OH}\left(\delta_{\mathrm{H}} 12.58\right)$ to C-10/C-10', C-5/C-5' and C-6/C-6' confirmed its placement at C-5/C-5'. The carbon C-9/C-9' $\left(\delta_{C} 128.2\right)$ was identified based on its HMBC correlation to H-7/H-7' $\left(\delta_{\mathrm{H}} 7.20\right)$. Most spectroscopic features of 1 were found similar to that of maritinone (8, $8^{\prime}$-biplumbagin) [14], lacking a proton at its C-8/C-8' and its molecular mass indicated that it is a symmetric dimer, connected via an oxygen bridge between its C- 8 and C- $8^{\prime}$. Based on the above spectroscopic evidence, the isolated compound 1 was identified as the new natural product $8,8^{\prime}$-oxo-biplumbagin. 
Table 1. ${ }^{1} \mathrm{H}$ and ${ }^{13} \mathrm{C}-\mathrm{NMR}$ data for $8,8^{\prime}$-oxo-biplumbagin (1).

\begin{tabular}{|c|c|c|c|}
\hline Position & $\delta_{\mathrm{H}}(\mathrm{I}, m, J$ in $\mathrm{Hz})$ & $\delta_{C}$ & $\operatorname{HMBC~}\left({ }^{2} J,^{3} J\right)$ \\
\hline $1,1^{\prime}$ & - & 185.2 & - \\
\hline $2,2^{\prime}$ & - & 150.0 & - \\
\hline $3,3^{\prime}$ & $6.80,(2 \mathrm{H}, \mathrm{q}, 1.6)$ & 134.9 & $\mathrm{C} 1, \mathrm{C}^{\prime}, \mathrm{C} 10, \mathrm{C} 10^{\prime}, \mathrm{C} 11, \mathrm{C} 11^{\prime}$ \\
\hline $4,4^{\prime}$ & - & 190.5 & - \\
\hline $5,5^{\prime}$ & - & 161.3 & - \\
\hline $6,6^{\prime}$ & $7.29,(2 \mathrm{H}, \mathrm{d}, 8.6)$ & 124.3 & $\begin{array}{c}\mathrm{C} 10, \mathrm{C} 10^{\prime}, \mathrm{C} 5, \mathrm{C}^{\prime}, \mathrm{C} 7, \mathrm{C}^{\prime} \\
\mathrm{C} 8, \mathrm{C} 8^{\prime}\end{array}$ \\
\hline $7,7^{\prime}$ & $7.20(2 \mathrm{H}, \mathrm{d}, 8.6)$ & 137.9 & $\begin{array}{c}\mathrm{C} 5, \mathrm{C}^{\prime}, \mathrm{C} 6, \mathrm{C}^{\prime}, \mathrm{C} 8, \mathrm{C} 8^{\prime}, \\
\mathrm{C} 9, \mathrm{C} 9^{\prime}\end{array}$ \\
\hline $8,8^{\prime}$ & - & 135.6 & - \\
\hline $9,9^{\prime}$ & - & 128.2 & - \\
\hline $10,10^{\prime}$ & - & 115.5 & - \\
\hline $11,11^{\prime}$ & $2.01(6 \mathrm{H}, \mathrm{d}, 1.6)$ & & $\mathrm{C} 1, \mathrm{C}^{\prime}, \mathrm{C} 2, \mathrm{C} 2^{\prime}, \mathrm{C} 3, \mathrm{C} 3^{\prime}$ \\
\hline $5-\mathrm{OH}, 5^{\prime}-\mathrm{OH}$ & $12.58(2 \mathrm{H}, \mathrm{brs})$ & - & $\mathrm{C} 10, \mathrm{C}_{10}^{\prime}, \mathrm{C} 5, \mathrm{C}^{\prime}, \mathrm{C} 6, \mathrm{C}^{\prime}$ \\
\hline
\end{tabular}

Based on their spectroscopic features, compounds 2-5 were identified (Supporting Information) as trans-isoshinanolone (2), cis-isoshinanolone (3) [15-25], plumbagin (4) [26-30], and $3,3^{\prime}$-biplumbagin (5) $[14,17,25]$. Of the five isolated compounds $\mathbf{1}, \mathbf{4}$, and 5 possess rigid planar 1,4-naphthoquinone skeletons whereas the saturated hydroxyl-cyclohexanone ring of 2 and 3 allow some conformational flexibility. In order to determine the solution conformation of the ring of the cis- and trans-analogues, a NAMFIS analysis was performed [31]. This technique has been successfully applied for the analysis of the conformation and flexibility of natural products [32], peptides [33], and synthetic bioactive substances [34,35]. Theoretically available conformations of $\mathbf{2}$ and $\mathbf{3}$ were generated using a Monte Carlo conformational search followed by molecular mechanic energy minimization, resulting in six and eight geometries, respectively. These were used as input conformations for NAMFIS analyses along with the observed NMR parameters ${ }^{3} J_{H 1}-H_{2},{ }^{3} J_{H 2}-H_{3} a,{ }^{3} J_{H 2}-H 3 b$, and NOE distances observed for $\mathrm{H} 2, \mathrm{H} 3$, and $\mathrm{H} 4$ using the NOEs observed for vicinal aromatic protons as internal distance reference $(2.5 \AA)$. NOESY spectra were acquired for $\mathrm{CDCl}_{3}$ solutions at an $800 \mathrm{MHz}$ Bruker Avance III spectrometer (Billerica, MA, USA) equipped with a TCI cryogenic probe, and using $700 \mathrm{~ms}$ mixing time and 2.5 s relaxation delay. Further experimental details are given in the Supporting Information. The ensemble analyses of $\mathbf{2}$ indicated the presence of three major solution conformations distributed in a 1:1:8 ratio, whereas the NAMFIS analysis of 3 revealed two major conformers distributed in a $1: 9$ ratio, with the energetically most advantaged geometry putting the 2-methyl substituent into equatorial position being favored (Tables S1 and S2 and Figure 2).
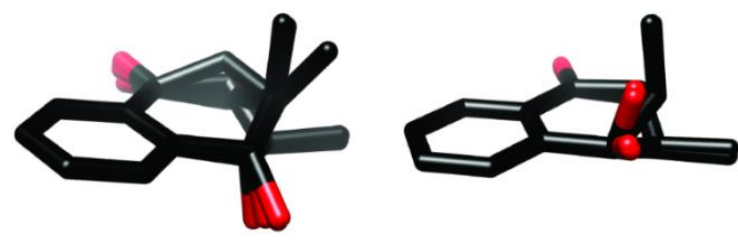

Figure 2. The solution conformations of compounds 2, to the left, and that of 3 , to the right, as determined by combined theoretical and solution NMR conformational analysis (NAMFIS) for chloroform solution.

\subsection{Cytotoxicity and Radical Scavenging Activities}

The Ebenaceae family is known as a rich source of naphthoquinones, whose quinone core is presumably capable of modulating oxidative biochemical processes [36]. The quinone structural element is common in cancer chemotherapeutic agents, such as doxorubicin, mitomycin $\mathrm{C}$, and mitoxantrone. Accordingly, herbal quinones were reported to possess cytotoxic activity [37-41]. 
Compounds 2, 4, and 5 were therefore assayed for activity against the MDA-MB-231 ER negative breast cancer cell line. Compounds $\mathbf{1}$ and $\mathbf{3}$ were only obtained in minute quantities and could therefore unfortunately not be assayed. Whereas 2 showed low toxicity, compounds 4 and 5 were active against the MDA-MB-231 cancer cells (Table 2). It should be noted here that 4 has previously been reported to exhibit anticancer, antileishmanial, antimicrobial, and antituberculotic activities [14,15,28,29,42], which may be exerted via a broad, general cytotoxicity. Accordingly, 4 was reported to cleave mammalian DNA through a topoisomerase II-mediated mechanism in vitro [43]. Moreover, in agreement with our above observations DNA-chelation of a hydroxyquinone moiety and iron was previously reported to result in complexes that generate reactive oxygen species (ROS), which may induce single strand breakage and lead to apoptosis [44].

Table 2. In vitro cytotoxic and radical scavenging activities (RSA) of the crude extracts and isolated constituents from D. shimbaensis.

\begin{tabular}{|c|c|c|}
\hline Tested Compound/Extract & Cytotoxicity $\mathrm{IC}_{50}{ }^{\mathrm{a}}$ & RSA EC ${ }_{50}^{b}(\mu \mathrm{M})$ \\
\hline $8,8^{\prime}$-Oxo-biplumbagin (1) & NT & $>25$ \\
\hline trans-Isoshinanolone (2) & $>520$ & $>25$ \\
\hline cis-Isoshinanolone (3) & NT & 12.5 \\
\hline Plumbagin (4) & 130.8 & $>25$ \\
\hline 3,3'-Biplumbagin (5) & 82.1 & $>25$ \\
\hline Methanol crude extract from the stem barks & 59.6 & NT \\
\hline Isohexane crude extract from the root barks & 16.1 & NT \\
\hline Dichloromethane crude extract from the root barks & 29.7 & NT \\
\hline Methanol crude extract from the root barks & $>100$ & NT \\
\hline Dichloromethane crude extract from the leaves & 73.0 & NT \\
\hline Methanol crude extract from the leaves & 44.7 & NT \\
\hline
\end{tabular}

In a radical scavenging activity (RSA) assay against 2,2-diphenyl-1-picrylhydrazyl (DPPH), the isolated constituents from D. shimbaensis showed moderate activity (Table 2 and Table S3) with cis-isoshinanolone (3) being the most effective. Their moderate RSA may be due to strong intramolecular chelation involving the phenolic hydrogen that is expected to be involved in the antioxidant activity. The observed relatively higher RSA of $\mathbf{3}$ as compared to its isomer 2 could be associated to their differences in conformation and configuration, which may influence their accessibility to the DPPH radical centre [45]. Generally, DNA damage accelerated by ROS of various types was pointed out as one of the major causes for cancer and degenerative diseases [10]. Also it has been shown that a number of compounds exhibiting antioxidant capabilities can alter cancer cell proliferation, migration, and survival through disruption of the cells redox state. In addition to the potential anti-cancer usage, plant constituents, such as 1-5, with RSA might be deployed for prevention and control of the degenerative diseases by modulating their antioxidant properties [46-49].

\section{Experimental Section}

\subsection{General Information}

Analytical HPLC was performed using a Hewlett Packard 1050 series instrument (Agilent Technologies Inc, Palo Alto, CA, USA) equipped with a Waters in-line degasser (Waters Corp, Milford, MA, USA) and a Gemini RP $5 \mu \mathrm{m}$ C18 column $(50 \times 4.6 \mathrm{~mm}$, Phenomenex, Torrance, CA, USA). Preparative HPLC was run on a Waters 600E HPLC system (Waters Corp) using the Chromulan software with XBridge C-18 column $(19 \times 150 \mathrm{~mm}$, Waters Corp) using water-methanol eluent mixtures. High-resolution mass spectrometric analyses (Q-TOF-MS) was done by Stenhagen Analyslab AB (Gothenburg, Sweden) using a Micromass Q-TOF micro instrument (Waters Corp) equipped with a lockmass-ESI source with $70 \mathrm{eV}$ ionization voltage. ${ }^{1} \mathrm{H}$ and ${ }^{13} \mathrm{C}-\mathrm{NMR}$ spectra were acquired at 
room temperature for $\mathrm{CDCl}_{3}$ solutions using a Bruker Avance III $800 \mathrm{MHz}\left({ }^{1} \mathrm{H}: 799.87 \mathrm{MHz},{ }^{13} \mathrm{C}\right.$ : 201.15 MHz), a Varian Unity $600 \mathrm{MHz}\left({ }^{1} \mathrm{H}: 599.77 \mathrm{MHz} ;{ }^{13} \mathrm{C}: 150.83 \mathrm{MHz}\right.$, Palo Alto, CA, USA), or a Varian VNMR-S $500 \mathrm{MHz}\left({ }^{1} \mathrm{H}: 499.58 \mathrm{MHz} ;{ }^{13} \mathrm{C}: 125.71 \mathrm{MHz}\right)$ spectrometer. Chemical shifts were referenced indirectly to tetramethylsilane via the residual solvent signal $\left(\mathrm{CDCl}_{3},{ }^{1} \mathrm{H}\right.$ at $7.26 \mathrm{ppm},{ }^{13} \mathrm{C}$ at $77.16 \mathrm{ppm})$. Spectra were processed using the software MestReNova (10.1, Mestrelab Research SL, Santiago de Compostela, Spain) and assignment was performed using ${ }^{1} \mathrm{H},{ }^{13} \mathrm{C}$, COSY [50], NOESY [51], HSQC [52], and HMBC [53] spectra. An Agilent 7820A Gas Chromatograph (Agilent Technologies Inc) with an Agilent 5977E MSD MS detector with EI (70 eV) ionization was applied for mass spectrometric analyses. IR spectra were acquired on a PerkinElmer Spectrum One FT-IR (Perkin Elmer Inc., Waltham, MA, USA).

\subsection{Plant Materials}

The stem and root barks of D. shimbaensis were collected in March 2013 from the Zaraninge Forest Reserve, Bagamoyo District, Pwani region in Tanzania at $300 \mathrm{~m}$ altitude. Field identification of the plant species was carried out by Mr. F. M. Mbago of the Herbarium of the Botany Department at the University of Dar es Salaam, where a voucher specimen (FMM 3614) was deposited.

\subsection{Extraction and Isolation}

The air-dried and pulverized stem bark $(2 \mathrm{~kg})$ was extracted by soaking twice in methanol for 48 $\mathrm{h}$ at room temperature. The filtrate of the extract was concentrated using a rotary evaporator yielding a dark yellowish crude extract (100 g). Portions of this crude (100 mg) were purified by preparative HPLC using a 70:30 to 100:0 water/methanol gradient for $60 \mathrm{~min}$, yielding 8,8'-oxo-bisplumbagin (1, $1.6 \mathrm{mg})$, trans-isoshinanolone $(2,10.6 \mathrm{mg})$, cis-isoshinanolone $(3,1.6 \mathrm{mg})$, plumbagin $(4,40.4 \mathrm{mg})$, and $3,3^{\prime}$-bisplumbagin $(5,1.4 \mathrm{mg})$.

The air dried and pulverized root bark $(1.2 \mathrm{~kg})$ was extracted consecutively in isohexane, dichloromethane, and methanol, by soaking twice for $48 \mathrm{~h}$ at room temperature. The filtrates were concentrated on a rotary evaporator yielding $6.8 \mathrm{~g}$ (isohexane), $11.2 \mathrm{~g}$ (dichloromethane), and $50.6 \mathrm{~g}$ (methanol) crude extracts, respectively. The constituents of the methanolic crude extract were isolated by preparative HPLC using a 70:30 to 100:0 water/methanol gradient for 60 min, yielding compounds 2 and 4 .

\subsection{Cytotoxicity Assay}

Cytotoxicity assay was performed on MDA-MB-231 human breast cancer cells using a previously described procedure [54,55]. In short, MDA-MB-231 cancer cells were cultured in Dulbecco's modified eagle medium (DMEM) supplemented with 10\% $(v / v)$ fetal bovine serum, $2 \mathrm{mM}$ L-glutamine, 100 units $/ \mathrm{mL}$ penicillin and $100 \mu \mathrm{g} / \mathrm{mL}$ streptomycin at $37{ }^{\circ} \mathrm{C}$ in humidified $5 \% \mathrm{CO}_{2}$. The cells were seeded in 96-well plates at optimal cell density (10,000 cells per well) to ensure exponential growth for the duration of the assay. After a $24 \mathrm{~h}$ pre-incubation growth period, the medium was replaced with the experimental medium containing the appropriate drug concentrations or vehicle controls $(0.1 \%$ or $1.0 \%$ v/v DMSO). After $72 \mathrm{~h}$ of incubation, cell viability was measured using the Alamar Blue reagent (Invitrogen Ab, Lidingö, Sweden), according to the manufacturer's instructions. Absorbance was measured at $570 \mathrm{~nm}$ with $600 \mathrm{~nm}$ as a reference wavelength. Results were expressed as mean \pm standard error for six replicates as a percentage of vehicle control (taken as $100 \%$ ). Extract or pure compound that showed $<80 \%$ viability was considered as a positive hit for cytotoxicity. Such extracts or compounds were further subjected to new cell library testing under serial dilutions to obtain $\mathrm{IC}_{50}$.

\subsection{Radical Scavenging Activities Assay}

The method described by Ohnishi et al. [56] was used with minor modifications. Test sample solutions of each compound at concentrations of $25,12.5,6.25$, and $3.13 \mu \mathrm{M}$ were prepared in methanol 
(HPLC grade). From each concentration, $1.0 \mathrm{~mL}$ sample was added to $2.0 \mathrm{~mL}$ of $50 \mu \mathrm{M}$ DPPH dissolved in methanol. The mixture was allowed to stand at room temperature for $30 \mathrm{~min}$, and the absorbance of the remaining DPPH was then measured at $515 \mathrm{~nm}$. The radical scavenging activity was measured as the decrease of the absorbance of the DPPH radical, expressed as a percentage of the absorbance of the control solution (1.0 mL of methanol mixed with $2.0 \mathrm{~mL}$ of $50 \mu \mathrm{M}$ DPPH solution). Radical scavenging activity was then expressed as effective concentration $\left(\mathrm{EC}_{50}\right)$, thus the concentration of the test compound required for $50 \%$ decrease in absorbance as compared to that of the control solution. The percentage of scavenged DPPH was calculated as $100 \times\left(\mathrm{A}_{\mathrm{DPPH}}-\mathrm{A}_{\text {Sample }}\right) / \mathrm{A}_{\mathrm{DPPH}}$, where $A_{D P P H}$ is the absorbance of the solution containing DPPH but without a test sample and $A_{\text {Sample }}$ is the absorbance of the mixture of the test sample and DPPH solution. Experiments were run in triplicate and $\mathrm{EC}_{50} \mathrm{~s}$ were determined by plotting the percentage of scavenged DPPH versus the initial concentration of each sample.

\section{Conclusions}

Phytochemical analysis of the stem and root barks of D. shimbaensis revealed tetralone and naphthoquinone metabolite content, in agreement with these being common chemotaxonomic markers for the genus Diospyros. 8, $8^{\prime}$-Oxo-biplumbagin is hereby reported for the very first time, whereas the isomeric tetralones cis- and trans-isoshinalonone and the naphthoquinones plumbagin and 3, $3^{\prime}$-biplumbagin are reported for the first time from $D$. shimbaensis. The isolated constituents showed moderate anticancer and radical scavenging activities, which is in line with the traditional medicinal use of the genus and may offer insights applicable in the development of future anticancer agents.

Supplementary Materials: Supplementary materials are accessible at: http://www.mdpi.com/2079-9721/4/1/3/s1.

Acknowledgments: Authors are grateful to the Swedish Research Council (grant No: 2012-6074) for financial support. We are grateful to Frank Mbago of the University of Dar es Salaam for identification of the investigated plant species.

Author Contributions: Plant materials were collected by S.S.N. and J.J.E.M. Stem barks were extracxted by S.S.N., the root barks by P.A. The constituents of the stem and root barks were purified by P.A. Spectroscopic identification of the pure compounds was carried out by J.J.E.M., P.A. and M.E. Cytotoxicity assays and related data analysis was carried out by A.G., P.A.F. and G.L. DPPH assay and data analysis was carried out by S.S.N. The manuscript was prepared by J.J.E.M., S.S.N. and M.E.

Conflicts of Interest: The authors declare no conflict of interest.

\section{References}

1. Thuong, P.T.; Lee, C.H.; Dao, T.T.; Nguyen, P.H.; Kim, W.G.; Lee, S.J.; Oh, W.K. Triterpenoids from the leaves of Diospyros kaki (Perimmon) and their inhibitory effects on protein tyrosine phosphatase 1B. J. Nat. Prod. 2008, 71, 1775-1778. [CrossRef] [PubMed]

2. Li, X.-C.; van der Bijl, P.; Wu, C.D. Binaphthalenone glycosides from African chewing sticks, Diospyros lycioides. J. Nat. Prod. 1998, 61, 817-820. [CrossRef] [PubMed]

3. Cai, L.; Wei, G.-X.; van der Bijl, P.; Wu, C.D. Namibian chewing stick, Diospyros lycioides, contains antibacterial compounds against oral pathogens. J. Agric. Food Chem. 2000, 48, 909-914. [CrossRef] [PubMed]

4. Gu, J.-G.; Graf, T.N.; Lee, D.; Chai, H.-G.; Mi, Q.; Kardono, L.B.S.; Setyowati, F.M.; Ismail, R.; Riswan, S.; Farnsworth, N.R.; et al. Cytotoxic and antimicrobial constituents of the bark of Diospyros maritima collected in two geographical locations in Indonesia. J. Nat. Prod. 2004, 67, 1156-1161. [CrossRef] [PubMed]

5. Chang, C.-I.; Chen, C.-R.; Chiu, H.-L.; Kuo, C.-L.; Kuo, Y.-H. Chemical constituents from the stems of Diospyros maritima. Molecules 2009, 14, 5281-5288. [CrossRef] [PubMed]

6. Mallavadhani, U.V.; Panda, A.K.; Rao, Y.R. Pharmacology and chemotaxonomy of Diospyros. Phytochemistry 1998, 49, 901-951. [CrossRef]

7. Watt, J.M.; Breyer-Brandwijk, M.G. Medicinal and Poisonous Plants of Southern and Eastern Africa; E\&S Livingstone limited: Edinburgh, UK, 1962.

8. Kokwaro, J.O. Medicinal Plants of East Africa; Kenya Literature Bureau: Nairobi, Kenya, 1993. 
9. Chhabra, S.C.; Mahunnah, R.L.A.; Mshiu, E.N. Plants used in traditional medicine in Eastern Tanzania. II. Angiospersm (Capparidaceae to Ebenaceae). J. Ethnopharmacol. 1989, 25, 339-359. [CrossRef]

10. Hook, I.; Mills, C.; Sheridan, H. Bioactive naphthoquinones from higher plants. Studies Nat. Prod. Chem. 2014, 41, 119-160.

11. Wallnöfer, B. The biology and systematics of Ebenaceae: A review. Ann. Naturhist. Mus. Wien. 2001, 103B, 485-512.

12. Diospyros shimbaensis, The IUCN red list of threatened species 1998: e.T33174A9756690. Available online: http:/ /dx.doi.org/10.2305/IUCN.UK.1998.RLTS.T33174A9756690.en (accessed on 13 November 2015).

13. Bringmann, G.; Wohlfarth, M.; Rischer, H.; Ruckert, M.; Schlauer, J. The polyketide folding mode in the biogenesis of isoshinanolone and plumbagin from Ancistrocladus heyneanus (Ancistrocladaceae). Tetrahedron Lett. 1998, 39, 8445-8448. [CrossRef]

14. Fournet, A.; Angelo, A.; Muñoz, V.; Roblot, F.; Hocquemiller, R.; Cavé, A. Biological and chemical studies of Pera benensis, a Bolivian plant used in folk medicine as a treatment of cutaneous leishmaniasis. J. Ethnopharmacol. 1992, 37, 159-164. [CrossRef]

15. Uc-Cachón, A.H.; Borges-Argáez, R.; Said-Fernández, S.; Vargas-Villarreal, J.; González-Salazar, F.; Méndez-González, M.; Cáceres-Farfán, M.; Molina-Salinas, G.M. Naphthoquinones isolated from Diospyros anisandra exhibit potent activity against pan-resistant first-line drugs Mycobacterium tuberculosis strains. Pulm. Pharmacol. Ther. 2014, 27, 114-120. [CrossRef] [PubMed]

16. Yue, J.-M.; Xu, J.; Zhao, Y.; Sun, H.-D.; Lin, Z.-W. Chemical components from Ceratostigma willmottianum. J. Nat. Prod. 1997, 60, 1031-1033. [CrossRef]

17. Anh, NH.; Ripperger, H.; Porzel, A.; van Sung, T.; Adam, G. Tetralones from Ancistrocladus cochinchinensis. Phytochemistry 1997, 41, 549-551.

18. Gunaherath, G.M.K.B.; Gunatilaka, A.A.L.; Sultanbawa, M.U.S.; Balasubramaniam, S. 1,2(3)-Tetrahydro3,3'-biplumbagin: A naphthalenone and other constituents from Plumbago zeylanica. Phytochemistry 1983, 22, 1245-1247. [CrossRef]

19. Zakaria, B.M.; Jeffreys, J.A.D.; Waterman, P.G.; Zhong, S.-M. Naphthoquinones and triterpenes from some Asian Diospyros species. Phytochemistry 1984, 23, 1481-1484. [CrossRef]

20. Kumar, V.; Meepagala, K.M.; Balasubramaniam, S. Quinonoid and other constituents of Aristea ecklonii. Phytochemistry 1985, 24, 1118-1119. [CrossRef]

21. Bhattacharyya, J.; de Carvalho, V.R. Epi-isoshinanolone from Plumbago scandens. Phytochemistry 1986, 25, 764-765. [CrossRef]

22. Zhong, S.-M.; Waterman, P.G.; Jeffreys, J.A.D. Naphthoquinones and triterpenes from African Diospyros species. Phytochemistry 1984, 23, 1067-1072. [CrossRef]

23. Hanson, S.W.; Crawford, M.; Thanasingh, D.P.J. (+)-Isoshinanolone and 2-methylbenzofuran-4-carbaldehyde from the fish-stunning plant Habropetalum dawei. Phytochemistry 1981, 20, 1162-1164. [CrossRef]

24. Bringmann, G.; Münchbach, M.; Messer, K.; Koppler, D.; Michel, M.; Schupp, O.; Wenzel, M.; Louis, A.M. cis- and trans-Isoshinanolone from Dioncophyllum thollonii: Absolute configuration of two 'known', wide-spread natural products. Phytochemistry 1999, 51, 693-699.

25. Tezuka, M.; Takahashi, C.; Kuroyanagi, M.; Satake, M.; Yoshihira, K.; Natori, S. New naphthoquinones from Diospyros. Phytochemistry 1973, 12, 175-183. [CrossRef]

26. Sreelatha, T.; Hymavathi, A.; Murthy, M.J.; Rani, P.U.; Rao, J.M.; Babu, K.S. Bioactivity-guided isolation of mosquitocidal constituents from the rhizomes of Plumbago capensis Thunb. Bioorg. Med. Chem. Lett. 2010, 20, 2974-2977. [CrossRef] [PubMed]

27. Kumagai, Y.; Shinkai, Y.; Miura, T.; Cho, A.K. The chemical biology of naphthoquinones and its environmental implications. Annu. Rev. Pharmacol. Toxicol. 2012, 52, 221-247. [CrossRef] [PubMed]

28. Padhye, S.; Dandawate, P.; Yusufi, M.; Ahmad, A.; Sarkar, F.H. Perspectives on medicinal properties of plumbagin and its analogs. Med. Res. Rev. 2012, 32, 1131-1158. [CrossRef] [PubMed]

29. Ahmad, A.; Banerjee, S.; Wang, Z.; Kong, D.; Sarkar, F.H. Plumbagin-induced apoptosis of human breast cancer cells is mediated by inactivation of NF- $\mathrm{kB}$ and Bcl-2. J. Cell. Biochem. 2008, 105, 1461-1471. [CrossRef] [PubMed]

30. Kuo, P.-L.; Hsu, Y.-L.; Cho, C.-Y. Plumbagin induces G2-M arrest and autophagy by inhibiting the AKT/mammalian target of rapamycin pathway in breast cancer cells. Mol. Cancer Ther. 2006, 12, 3209-3221. [CrossRef] [PubMed] 
31. Cicero, D.O.; Barbato, G.; Bazzo, R. NMR analysis of molecular flexibility in solution: A new method for the study of complex distributions of rapidly exchanging conformations. Application to a 13-residue peptide with an 8-residue loop. J. Am. Chem. Soc. 1995, 117, 1027-1033. [CrossRef]

32. Erdelyi, M.; Pfeiffer, B.; Hauenstein, K.K.; Forher, J.; Gertsch, J.; Altmann, K.H.; Carlomagno, T. Conformational preferences of natural and C3-modified epothilones in aqueous solution. J. Med. Chem. 2008, 51, 1469-1473. [CrossRef] [PubMed]

33. Danelius, E.; Brath, U.; Erdelyi, M. Insight into beta-hairpin stability: Intrastrand hydrogen bonding. Synlett 2013, 24, 2407-2410.

34. Andersson, H.; Demaegdt, H.; Vauquelin, G.; Lindeberg, G.; Karlén, A.; Hallberg, M.; Erdelyi, M.; Hallberg, A.J. Disulfide cyclized tripeptide analogues of angiotensin IV as potent and selective inhibitors of insulin-regulated aminopeptidase (IRAP). J. Med. Chem. 2010, 53, 8059-8071. [CrossRef] [PubMed]

35. Friden-Saxin, M.; Seifert, T.; Hansen, L.K.; Grötli, M.; Erdelyi, M.; Luthman, K. Proline-mediated formation of novel chroman-4-one tetrahydropyrimidines. Tetrahedron 2012, 68, 7035-7040. [CrossRef]

36. Monks, T.J.; Jones, D.C. The metabolism and toxicity of quinones, quinonimines, quinine methides and quinone-thioethers. Curr. Drug Metable 2002, 3, 425-438. [CrossRef]

37. Huang, Q.; Lu, G.; Sben, H.M.; Cbung, M.C.M.; Ong, C.N. Anti-cancer properties of anthraquinones from rhubarb. Med. Res. Rev. 2007, 27, 609-630. [CrossRef] [PubMed]

38. Endale, M.; Alao, J.P.; Akala, H.M.; Rono, N.K.; Eyase, F.L.; Derese, S.; Ndakala, A.; Mbugua, M.; Walsh, D.S.; Sunnerhagen, P.; et al. Antiplasmodial quinones from Pentas longiflora and Pentas lanceolata. Planta Med. 2012, 78, 31-35. [CrossRef] [PubMed]

39. Queiroz, M.L.; Valadares, M.C.; Torello, C.O.; Ramos, A.L.; Oliveira, A.B.; Rocha, F.D.; Arruda, V.A.; Accorci, W.R. Comparative studies of the effects of Tabebuia avellanedae bark extract and $\beta$-lapachone on the hematopoietic response of tumour-bearing mice. J. Ethnopharmacol. 2008, 117, 228-235. [CrossRef] [PubMed]

40. Lim, E.S.; Rhee, Y.H.; Park, M.K.; Shim, B.S.; Ahn, K.S.; Kang, H.; Yoo, H.S.; Kim, S.H. DMNQ S-64 induces apoptosis via caspase activation and cyclooxygenase-2 inhibition in human non-small lung cancer cells. Ann. N. Y. Acad. Sci. 2007, 1095, 7-18. [CrossRef] [PubMed]

41. Lu, J.J.; Bao, J.L.; Wu, G.S.; Xu, W.S.; Huang, M.Q.; Chen, X.P.; Wang, Y.T. Quinones derived from plant secondary metabolites as anti-cancer agents. Anticancer Agents Med. Chem. 2013, 13, 456-463. [CrossRef] [PubMed]

42. Sinha, S.; Pal, K.; Elkhanany, A.; Dutta, S.; Cao, Y.; Mondal, G.; Iyer, S.; Somasundaram, V.; Couch, F.J.; Shridhar, V. Plumbagin inhibits tumorigenesis and angiogenesis of ovarian cancer cells in vivo. Int. J. Cancer 2013, 132, 1201-1212. [CrossRef] [PubMed]

43. Fujii, N.; Yamashita, Y.; Arima, Y.; Nagashima, M.; Nakano, H. Induction of topoisomerase II-mediated DNA cleavage by the plant naphthoquinones, plumbagin and shikonin. Antimicrob. Agents Chemother. 1992, 36, 2589-2594. [CrossRef] [PubMed]

44. Lee, J.-H.; Yeon, J.-H.; Kim, H.; Roh, W.; Chae, J.; Park, H.-O.; Kim, D.-M. The natural anticancer agent plumbagin induces potent cytotoxicity in MCF-7 human breast cancer cells by inhibiting a PI-5 kinase for ROS generation. PLoS ONE 2012, 7, e45023. [CrossRef] [PubMed]

45. Hussein, M.A. A convenient mechanism for the free radical scavenging activity of resveratrol. Int. J. Phytomed. 2011, 3, 459-469.

46. Hsieh, T.-C.; Elangovan, S.; Wu, J.M. Differential suppression of proliferation in MCF-7 and MDA-MB-231 breast cancer cells exposed to $\alpha-, \gamma$ - and $\delta$-tocotrienols is accompanied by altered expression of oxidative stress modulatory enzymes. Anticancer Res. 2010, 30, 4169-4176. [PubMed]

47. Srinivas, P.; Patra, C.R.; Bhattacharya, S.; Mukhopadhyay, D. Cytotoxicity of naphthoquinones and their capacity to generate reactive oxygen species is quenched when conjugated with gold nanoparticles. Int. J. Nanonmed. 2011, 6, 2113-2122. [CrossRef] [PubMed]

48. Abdullah, A.-S.H.; Mohammed, A.S.; Rasedee, A.; Mirghani, M.E.S.; Al-Qubaisi, M.S. Induction of apoptosis and oxidative stress in estrogen receptor-negative breast cancer, MDA-MB231 cells, by ethanolic mango seed extract. BMC Complement. Altern. Med. 2010, 15, 45-52. [CrossRef] [PubMed]

49. Dinicola, S.; Cucina, A.; Antonacci, D.; Bizzarri, M. Anticancer effects of grape seed extract on human cancers: A review. J. Carcinog. Mutagen. 2014. [CrossRef]

50. Wokaun, A.; Ernst, R.R. Selective detection of multiple quantum transitions in NMR by 2-dimensional spectroscopy. Chem. Phys. Lett. 1977, 52, 407-412. [CrossRef] 
51. Kumar, A.; Ernst, R.R.; Wüthrich, K. A two-dimensional nuclear Overhauser enhancement (2D NOE) experiment for the elucidation of complete proton-proton cross-relaxation networks in biological macromolecules. Biochem. Biophys. Res. Commun. 1980, 95, 1-6. [CrossRef]

52. Hurd, R.E.; John, B.K. Gradient-enhanced proton-detected heteronuclear multiple-quantum coherence spectroscopy. J. Magn. Reson. 1991, 91, 648-653. [CrossRef]

53. Perpickdumont, M.; Reynolds, W.F.; Enriquez, R.G. ${ }^{13} \mathrm{C}-{ }^{1} \mathrm{H}$ shift correlation with full ${ }^{1} \mathrm{~h}-{ }^{1} \mathrm{H}$ decoupling. Magn. Reson. Chem. 1988, 26, 358-361. [CrossRef]

54. Negera, A.; Induli, M.; Fitzpatrick, P.; Alao, J.P.; Sunnerhagen, P.; Landberg, G.; Yenesew, A.; Erdélyi, M. Cytotoxic quinones from the roots of Aloe dawei. Molecules 2014, 19, 3264-3273.

55. Irungu, B.N.; Orwa, J.A.; Gruhonjic, A.; Fitzpatrick, P.A.; Landberg, G.; Kimani, F.; Midiwo, J.; Erdélyi, M.; Yenesew, A. Constituents of the roots and leaves of Ekebergia capensis and their potential antiplasmodial and cytotoxic activities. Molecules 2014, 19, 14235-14246. [CrossRef] [PubMed]

56. Ohnishi, S.T.; Kojima, R. In vitro antioxidant activity of an aged garlic extract. FASEB J. 1994, 8, A596.

(C) 2016 by the authors; licensee MDPI, Basel, Switzerland. This article is an open access article distributed under the terms and conditions of the Creative Commons by Attribution (CC-BY) license (http:/ / creativecommons.org/licenses/by/4.0/). 